\title{
Boto, a class II transposon in Moniliophthora perniciosa, is the first representative of the PIF/ Harbinger superfamily in a phytopathogenic fungus
}

Correspondence

Marisa V. de Queiroz

mvqueiro@ufv.br
Received 15 August 2012 Revised 22 October 2012 Accepted 24 October 2012
Jorge Fernando Pereira, ${ }^{1} \dagger$ Ana Paula Morais Martins Almeida, ${ }^{1} \ddagger$ Júnio Cota, ${ }^{1} \S$ João Alencar Pamphile, ${ }^{2}$ Gilvan Ferreira da Silva, ${ }^{1} \|$ Elza Fernandes de Araújo, ${ }^{1}$ Karina Peres Gramacho, ${ }^{3}$ Sérgio Hermínio Brommonschenkel, ${ }^{4}$ Gonçalo Amarante Guimarães Pereira ${ }^{5}$ and Marisa Vieira de Queiroz ${ }^{1}$

\author{
${ }^{1}$ Universidade Federal de Viçosa, Departamento de Microbiologia, CEP 36571-000, Viçosa, MG, \\ Brazil \\ ${ }^{2}$ Universidade Estadual de Maringá, Departamento de Biologia Celular e Genética, \\ CEP 87020-900, Maringá, PR, Brazil \\ ${ }^{3}$ CEPLAC, Centro de Pesquisa do Cacau, CEP 45600-000, Itabuna, BA, Brazil \\ ${ }^{4}$ Universidade Federal de Viçosa, Departamento de Fitopatologia, CEP 36571-000, Viçosa, MG, \\ Brazil \\ ${ }^{5}$ Universidade Estadual de Campinas, Departamento de Genética e Evolução, CEP 13083-970, \\ Campinas, SP, Brazil
}

\begin{abstract}
Boto, a class II transposable element, was characterized in the Moniliophthora perniciosa genome. The Boto transposase is highly similar to plant PIF-like transposases that belong to the newest class II superfamily known as PIF/Harbinger. Although Boto shares characteristics with PIF-like elements, other characteristics, such as the transposase intron position, the position and direction of the second ORF, and the footprint, indicate that Boto belongs to a novel family of the PIF/Harbinger superfamily. Southern blot analyses detected 6-12 copies of Boto in C-biotype isolates and a ubiquitous presence among the C- and S-biotypes, as well as a separation in the C-biotype isolates from Bahia State in Brazil in at least two genotypic groups, and a new insertion in the genome of a C-biotype isolate maintained in the laboratory for 6 years. In addition to PCR amplification from a specific insertion site, changes in the Boto hybridization profile after the $M$. perniciosa sexual cycle and detection of Boto transcripts gave further evidence of Boto activity. As an active family in the genome of $M$. perniciosa, Boto elements may contribute to genetic variability in this homothallic fungus. This is the first report of a PIF/Harbinger transposon in the genome of a phytopathogenic fungus.
\end{abstract}

tPresent address: Embrapa Trigo, Rodovia BR 285 Km 294, CEP 99001-970, Passo Fundo, RS, Brazil.

$\ddagger$ Present address: Universidade Federal de Minas Gerais, Departamento de Microbiologia, Av. Antônio Carlos 6627, CEP 31270-901, Belo Horizonte, MG, Brazil.

§Present address: Laboratório Nacional de Ciência e Tecnologia do Bioetanol, Rua Giuseppe Máximo Scolfaro 10000, CEP 13083-970, Campinas, SP, Brazil.

||Present address: Embrapa Amazônia Ocidental, Rodovia AM-010 Km 29, CEP 69010-970, Manaus, AM, Brazil.

Abbreviations: IS, insertion sequence; MITE, miniature inverted-repeated transposable element; TIR, terminal inverted repeat; TSD, target site duplication.

The GenBank/EMBL/DDBJ accession number for the Boto sequence reported in this paper is EU218539.

\section{INTRODUCTION}

Eukaryotic transposable elements are divided into two main categories according to their transposition mechanism: the class I elements that transpose by an intermediate RNA and are further divided into the five orders LTR, DIRS, Penelope-like, LINEs and SINEs (Wicker et al., 2007); and the class II elements that transpose directly at the DNA level, not requiring an RNA transposition intermediate. Class II elements can be further divided into subclasses, superfamilies and families by the transposition mechanisms and structural features of the terminal inverted repeats (TIRs), the transposase and the target site duplication (TSD) (Daboussi \& Capy, 2003; Wicker et al., 2007). Class II elements belonging to the 
superfamilies Tcl/mariner, hAT, mutator and MITEs (miniature inverted-repeated transposable elements) have already been identified in several species of filamentous fungi (Daboussi \& Capy, 2003). Moreover, as new elements are described and new eukaryotic genomes are sequenced, new groups of elements are identified (Goodwin \& Poulter, 2001; Goodwin et al., 2003).

One of the 10 class II superfamilies identified so far in eukaryotic organisms is the PIF/Harbinger superfamily. The first two elements described in this superfamily were the PIF element ( $\mathrm{P}$ instability factor) of maize (Walker et al., 1997) and the Harbinger element of Arabidopsis thaliana (Kapitonov \& Jurka, 1999). PIF/Harbinger elements share characteristics with other groups of transposons, such as the small TIRs and the 3 bp TSD. However, some unique characteristics distinguish PIF/Harbinger elements from other superfamilies: (i) the presence of two open reading frames (ORFs), one coding for a transposase and the other for a protein of unknown function but showing weak similarity to $m y b$ transcription factors (Jiang et al., 2003); (ii) a distant relationship between the PIF/Harbinger transposase and the transposase of bacterial insertion sequences (IS) of the IS 5 group; and (iii) their direct link in origin and mobility of nonautonomous MITEs (Zhang et al., 2001, 2004; Grzebelus et al., 2006). The Harbinger and PIF elements, in addition to the rice element named Pong (Zhang et al., 2004), can be seen as the founding members of this widespread superfamily of DNA transposons. A distribution analysis identified more than 600 PIF-like transposases from 35 species of plants and 19 species of animals (Zhang et al., 2004), and different PIF/Harbinger families have been found in protists, plants, insects, worms and vertebrates (Jurka \& Kapitonov, 2001; Kapitonov \& Jurka, 2004; Grzebelus et al., 2006; Zhou et al., 2010, 2012). Curiously, sequences similar to PIF-like elements were reported in only two species of fungi, Cryptococcus neoformans and Neurospora crassa (Zhang et al., 2001, 2004). This observation is interesting because a great number of transposable elements from varying superfamilies have been identified in fungal genomes (Wöstemeyer \& Kreibich, 2002; Daboussi \& Capy, 2003; Pereira et al., 2006).

Mutagenic effects of transposons could be one of the main mechanisms responsible for the high adaptability and plasticity exhibited by numerous species of pathogenic fungi (Daboussi \& Capy, 2003; Shnyreva, 2003; Pereira et al., 2006; Schmidt \& Panstruga, 2011). In this context, studying transposable elements in the plant pathogen Moniliophthora (formerly Crinipellis) perniciosa, the causal agent of witches' broom disease of cacao, is important to understand the mechanisms related to genetic variability in this species. This fungus attacks cacao plantations in South and Central America and represents the main threat in south-eastern Bahia, the main cacao-producing region in Brazil (Pereira et al., 1996). In addition to cacao (Theobroma cacao), M. perniciosa has other plant hosts, and a classification based on pathological data divides the species into the following three biotypes: the C-biotype infects species of the family Sterculiaceae (Evans, 1978; Bastos et al., 1988), the S-biotype infects plants of the family Solanaceae (Bastos \& Evans, 1985; Bastos et al., 1988) and the L-biotype is a saprotroph that colonizes a wide variety of substrates (Evans, 1978; Hedger et al., 1987). The genetic variability of $M$. perniciosa has been evaluated through different molecular studies that revealed a high degree of variability among isolates of this species (Andebrhan \& Furtek, 1994; Andebrhan et al., 1999; de Arruda et al., 2003a, b; Rincones et al., 2003, 2006; Ploetz et al., 2005).

In the present work, we describe the isolation and characterization of a class II transposable element in the M. perniciosa genome. This element, called Boto, is the first representative of the PIF/Harbinger superfamily identified in a phytopathogenic fungus.

\section{METHODS}

Fungal strains and growth conditions. Isolates of $M$. perniciosa examined in the present study are listed in Table 1. Basidiomata from isolate 1919 were obtained from mycelial mats as described by Griffith \& Hedger (1993) with the modifications introduced by Niella et al. (1999).

Isolation of recombinant phages. A sequence showing similarity to plant PIF-like transposase (e-value $1 \times 10^{-29}$ ) was obtained from the database of the Witches' Broom Genome Project. Primers CPORT1 (5'-TTGCTTGTGAGCTTGGTGTC) and CPORT2 (5'GCCTGAGCATGTCGAAGATT) were used to amplify a $795 \mathrm{bp}$ fragment corresponding to part of the transposase coding region that was subsequently used as a probe for the isolation of recombinant phages from a genomic library of $M$. perniciosa cloned into the 2EMBL3 bacteriophage (Benton \& Davis, 1977). Hybridizations were conducted at $65{ }^{\circ} \mathrm{C}$ using the Gene Images Random Primer Labelling Module and the CDP-Star Detection Module (Amersham Biosciences) according to the manufacturer's instructions. The plates containing the positive phages were individually collected, and second and third screenings were conducted using the same conditions described above. DNA was extracted from the positive phages following the protocol described by Felipe et al. (1992). Cleavage of the phage DNA was performed using different restriction enzymes according to the manufacturer's instructions.

Cloning of the Boto element, sequencing and sequence analysis. Fragments generated from the digestion of the isolated phages were cloned into the pBluescript II KS + vector (Stratagene). DNA sequencing was performed according to the dideoxynucleotide chain-termination method (Sanger et al., 1977) in a MegaBACE 500 sequencer (Amersham Biosciences). Analyses of DNA and protein sequences were performed using the BLAST algorithm (Altschul et al., 1997), CLUSTAL W program (Thompson et al., 1994), the CD-Search program to identify conserved domains (Marchler-Bauer \& Bryant, 2004) and the AUGUSTUS program for gene prediction (Stanke \& Morgenstern, 2005).

Phylogenetic analysis. The sequences of the fungal, oomycete, plant and animal PIF/Harbinger transposase proteins were obtained from GenBank. The sequences were aligned using the CLUSTAL W program, and phylogenetic analyses were performed based on the 
Table 1. Isolates of Moniliophtora perniciosa used in this study

\begin{tabular}{|c|c|c|c|c|c|}
\hline $\begin{array}{l}\text { Isolate } \\
\text { number }\end{array}$ & Isolate identification & Biotype & Chromosomal group ${ }^{*}$ & Location $\dagger$ & Host \\
\hline 1 & FA551 & $\mathrm{C}$ & - & Tabatinga/AM & Theobroma sp. \\
\hline 3 & ESJOH2 & $\mathrm{C}$ & - & Ouro Preto do Oeste/RO & Theobroma cacao \\
\hline 4 & ESJOH3 & $\mathrm{C}$ & - & Belém/PA & Theobroma cacao \\
\hline 5 & СР02-1 & $\mathrm{C}$ & $\mathrm{CP}-\mathrm{C} 1$ & Itajaípe/BA & Theobroma cacao \\
\hline 7 & Ilhéus & $\mathrm{C}$ & $\mathrm{CP}-\mathrm{C} 1$ & Ilhéus/BA & Theobroma sp. \\
\hline 8 & FA563 & $\mathrm{C}$ & $\mathrm{CP}-\mathrm{C} 1$ & Itabuna/BA & Theobroma cacao \\
\hline 9 & Santo Amaro & $\mathrm{C}$ & $\mathrm{CP}-\mathrm{C} 2$ & Santo Amaro/BA & Theobroma sp. \\
\hline 10 & FA42 & $\mathrm{C}$ & $\mathrm{CP}-\mathrm{C} 2$ & Itabuna/BA & Theobroma cacao \\
\hline 11 & FA276 & $\mathrm{C}$ & $\mathrm{CP}-\mathrm{C} 2$ & Itabuna/BA & Theobroma cacao \\
\hline 12 & FA293 & $\mathrm{C}$ & - & Gandu/BA & Theobroma cacao \\
\hline 17 & FA607 & S & - & Coimbra/MG & Solanum lycocarpum \\
\hline 18 & FA609 & S & - & Poços de Caldas/MG & Solanum sp. \\
\hline 19 & DOA-105 & S & - & Jataí/GO & Solanum lycocarpum \\
\hline 20 & LA17 & $\mathrm{L}$ & - & Pichilingue/Ecuador & Arrabidaea verrucosa \\
\hline 21 & RWB500 & $S$ & - & Mariana/MG & Solanum cernum \\
\hline 22 & RWB551 & $S$ & - & Juiz de Fora/MG & Solanum lycocarpum \\
\hline 23 & FA277 & $\mathrm{C}$ & - & Itabuna/BA & Theobroma cacao \\
\hline 24 & FA281 & $\mathrm{C}$ & $\mathrm{CP}-\mathrm{C} 2$ & Aiquara/BA & Theobroma cacao \\
\hline 25 & DOA100 & $\mathrm{C}$ & - & - & Theobroma cacao \\
\hline 26 & $\mathrm{CP} 02 \ddagger$ & $\mathrm{C}$ & $\mathrm{CP}-\mathrm{C} 1$ & Itajaípe/BA & Theobroma cacao \\
\hline 27 & ALF42 & $\mathrm{C}$ & - & Itabuna/BA & Theobroma cacao \\
\hline 35 & 606GD-W & $\mathrm{C}$ & - & Itabuna/BA & Theobroma cacao \\
\hline 36 & 676GD-W & $\mathrm{C}$ & - & Floresta Azul/BA & Theobroma cacao \\
\hline 37 & 896FD-W & $\mathrm{C}$ & - & Jaguaquara/BA & Theobroma cacao \\
\hline 38 & 948FD-W & $\mathrm{C}$ & - & - & Theobroma cacao \\
\hline 39 & $1734 \mathrm{D}-\mathrm{W}$ & $\mathrm{C}$ & - & Gandu/BA & Theobroma cacao \\
\hline 40 & FA317 & $\mathrm{C}$ & - & - & Theobroma cacao \\
\hline 41 & SABA & $\mathrm{C}$ & - & - & Theobroma cacao \\
\hline- & 1919 & $\mathrm{C}$ & - & - & Theobroma cacao \\
\hline
\end{tabular}

${ }^{\star}$ Chromosomal groups 1 or 2 determined according to Rincones et al. (2006).

$\dagger$ AM, Amazonas; BA, Bahia; GO, Goiás; MG, Minas Gerais; PA, Pará; RO, Rondônia.

¥Isolate CP02 was used in the Witches’ Broom Genome Project.

neighbour-joining method (Saitou \& Nei, 1987) using bootstrap values based on 1000 replicates.

Footprint analysis. Primers Boto2.1 (5'-TGTAGGCATTCGGACTTTCGG) and Boto2.2 (5'-TTCGGATGCTCTTGCCGT) were designed based on the Boto flanking regions present in the $\lambda$ phage 2.1.1. The expected $185 \mathrm{bp}$ PCR fragment was precipitated and used for sequencing as described above.
DNA extraction and PCR amplification. Total DNA was extracted as described by Specht et al. (1982). The PCR amplification was performed in a thermocycler (PTC-100; MJ Research) with the following programme: for primers CPORT1 and CPORT2, 40 cycles of $1 \mathrm{~min}$ at $94{ }^{\circ} \mathrm{C}, 1 \mathrm{~min}$ at $55^{\circ} \mathrm{C}$ and $1 \mathrm{~min}$ at $72{ }^{\circ} \mathrm{C}$, and a final extension step at $72{ }^{\circ} \mathrm{C}$ for $10 \mathrm{~min}$; and for primers Boto2.1 and Boto2.2, 30 cycles of $30 \mathrm{~s}$ at $94{ }^{\circ} \mathrm{C}, 30 \mathrm{~s}$ at $62{ }^{\circ} \mathrm{C}$ and $30 \mathrm{~s}$ at $72{ }^{\circ} \mathrm{C}$, and a final extension step at $72{ }^{\circ} \mathrm{C}$ for $3 \mathrm{~min}$. The reactions were carried out 
in a final volume of $25 \mu \mathrm{l}$ containing $1 \times$ thermophilic DNA poly Buffer (Promega), $2.5 \mathrm{mM} \mathrm{MgCl} 2,400 \mu \mathrm{M}$ dNTPs, $0.2 \mu \mathrm{M}$ each primer, 50 ng total DNA and 1 unit Taq DNA Polymerase (Promega).

Southern hybridization analysis. For phage characterization, the viral DNA $(2 \mu \mathrm{g})$ was digested with the restriction enzymes BamHI, EcoRI, HindIII, KpnI and SalI (data not shown). After the sexual cycle in the M. perniciosa isolates, the distribution, copy number analyses and hybridization profiles were performed with total DNA $(3 \mu \mathrm{g})$ digested with HindIII or SalI. These enzymes do not cut inside the $795 \mathrm{bp}$ transposase fragment used as the probe. The digested DNA was then electrophoresed in a $0.7 \%$ agarose gel and transferred to a Duralon-UV nylon membrane (Stratagene) following standard procedures (Sambrook et al., 1989). HindIII-cleaved DNA was hybridized at $58{ }^{\circ} \mathrm{C}$ but that temperature exhibited low specificity for the SalI-cleaved DNA, making the results difficult to interpret. Subsequently, hybridization with the Sall-cleaved DNA was performed at $65{ }^{\circ} \mathrm{C}$. Probe labelling, hybridization and detection were performed with the Gene Images Random Primer Labelling Module and the CDP-Star Detection Module (Amersham Biosciences) according to the manufacturer's instructions.

RNA extraction, RT-PCR analysis and CDNA cloning. To obtain the $M$. perniciosa mycelial mass for the RT-PCR experiment, five mycelial discs ( $7 \mathrm{~mm}$ each) were placed in PDA medium at $27{ }^{\circ} \mathrm{C}$ for 10 days. Once grown, 10 mycelial discs were cut into smaller fragments and transferred to $125 \mathrm{ml}$ Erlenmeyer flasks containing $50 \mathrm{ml}$ Pontecorvo's minimal medium (Pontecorvo et al., 1953) and incubated for 7 days at $27{ }^{\circ} \mathrm{C} / 180$ r.p.m. Mycelia were subsequently separated from the media, washed three times and frozen in liquid nitrogen. Total RNA extraction was performed according to TRIzolbased methods (Invitrogen). For the RT reactions, total RNA was treated with DNase RQI RNase-Free (Promega) and quantified spectrophotometrically at $260 \mathrm{~nm}$. To synthesize the first cDNA strand, the reaction components were mixed as follows: $5 \mu \mathrm{g}$ total RNA, $1 \times$ RT reaction buffer (Promega), $0.5 \mathrm{mM}$ dNTPs, $500 \mathrm{ng}$ $(\mathrm{dT})_{15}$ primer (Promega), 20 units of the RNase inhibitor RNAsin (Promega) and 10 units AMV Reverse Transcriptase (Promega). The reaction mixtures were adjusted to a final volume of $20 \mu \mathrm{l}$ and incubated at $25{ }^{\circ} \mathrm{C}$ for $5 \mathrm{~min}$ followed by $60 \mathrm{~min}$ at $42{ }^{\circ} \mathrm{C}$. Primers CPORT1 and CPORT2 were used to amplify a fragment of the Boto transposase coding region. The expected size of the amplification product is 795 or $694 \mathrm{bp}$, depending on whether genomic DNA or cDNA is used as the template, respectively. The programme used for this amplification was 25 cycles of $1 \mathrm{~min}$ at $94{ }^{\circ} \mathrm{C}, 1 \mathrm{~min}$ at $55^{\circ} \mathrm{C}$ and $1 \mathrm{~min}$ at $72{ }^{\circ} \mathrm{C}$. The entire $25 \mu \mathrm{l}$ amplification reaction was electrophoresed in a $1.5 \%$ agarose gel. To analyse the Boto ORF1 expression, two primer sets, Boto2ORF1F1 (5'-AGTCTTCGGCAACCAATGAG) plus Boto2ORF1R1 (5'-CCTCGGGTTGGCCTTAACATA) and Boto2ORF1F2 (5'-CAGAGCCAAACAGTGCAAAA) plus Boto2ORF1R2 (5'-CCGAGACACTCAATCCACCTG), were used. The size of the PCR product was expected to be either 402 or $347 \mathrm{bp}$ and 896 or $794 \mathrm{bp}$, depending on whether genomic DNA or cDNA was used as the template, respectively. The programme used for this amplification was 35 cycles of $1 \mathrm{~min}$ at $94{ }^{\circ} \mathrm{C}, 1 \mathrm{~min}$ at $51{ }^{\circ} \mathrm{C}$ and $1 \mathrm{~min}$ at $72{ }^{\circ} \mathrm{C}$. The reaction mixture was electrophoresed in a $2.5 \%$ agarose gel. The amplified cDNA from Boto transposase and ORF1 was cloned into the pGEM-T Easy vector (Promega) according to the manufacturer's instructions. Sequencing and analysis of the cDNA were performed as described above.

\section{RESULTS}

\section{Boto belongs to the PIF/IS5 superfamily}

Our group had previously designed a phage (2EMBL3) genomic library of $M$. perniciosa aimed at isolating complete and intact genes when only a partial gene sequence was available in the Witches' Broom Genome Project database, which was common at the beginning of the project. DNA from isolate $\mathrm{CP} 02$, the same isolate used in the Witches' Broom Genome Project, was used as the template for primers CPORT1 and CPORT2. A $795 \mathrm{bp}$ DNA fragment, amplified by those primers and containing part of a transposase sequence, was used as a probe to screen for recombinant phages (data not shown). A $4 \mathrm{~kb}$ EcoRI fragment from phage 2.1.1 was cloned and sequenced. The resulting sequence corresponds to the element designated Boto. This element is $3089 \mathrm{bp}$ and has TIRs of $45 \mathrm{bp}$ (5'-GGGCCTGTTCGGTAAAAAAAAGCTGTAGCTTTTTCGCAGCTTTTC and 5'-GAAAAGCTACGAAAAAGCTGCAGCTTTTTTTTACCGAACAGGCCC) with $95.55 \%$ identity, varying only in two base pairs. A $3 \mathrm{bp}$ sequence (TAA) was found flanking the Boto TIRs, thus characterizing the putative TSD. An ORF beginning $127 \mathrm{bp}$ downstream of the $5^{\prime}$ TIR codes for a 414 aa protein, showing high similarity to transposases of plant PIF-like elements and hypothetical proteins of Cryptococcus neoformans, Cryptococcus gattii and Ajellomyces capsulatus (e-values from $2 \times 10^{-53}$ to $7 \times 10^{-46}$ ). Therefore, although fungal PIF/Harbinger transposases have been previously described only for C. neoformans and N. crassa (Zhang et al., 2001, 2004), new PIF/Harbinger transposases from two fungal species were found in GenBank. In addition to the $3 \mathrm{bp}$ TSD and the similarity to PIF-like transposases, two other characteristics indicate that Boto is a member of the PIF/Harbinger superfamily: (i) the presence of two introns at the transposase coding region, and (ii) the presence of a second ORF coding for a protein of unknown function (Fig. 1).

\section{Boto transposase contains two introns}

Comparison of the Boto transposase with transposases of plant PIF/Harbinger elements revealed the presence of some conserved domains (Fig. 1c). These domains have already been described in transposases of plant PIF-like elements (Zhang et al., 2004) and correspond to (i) the HTH domain (helix-turn-helix), which could participate in DNA binding, and to (ii) the N2, N3 and $\mathrm{C} 1$ regions that probably contain the protein catalytic domain, given that they contain the characteristic DDE amino acid residues (Asp, Asp and Glu), with one residue located in each region. The Boto transposase was found to have the same $\mathrm{DD}^{48} \mathrm{E}$ spacing reported for some transposases of plant PIF-like elements, which can also have the $\mathrm{DD}^{47} \mathrm{E}$ spacing (Zhang et al., 2004). For the Harbinger and Pong transposases, this motif can be seen as $\mathrm{DD}^{35} \mathrm{E}$ (Kapitonov \& Jurka, 1999, 2004; Zhang et al., 2004).

The first intron (53 bp) in the Boto transposase coding region interrupts the $\mathrm{His}^{133}$ codon and has an $\mathrm{A}+\mathrm{T}$ content of $68 \%$. The second intron (48 bp) interrupts the $\mathrm{Arg}^{285}$ codon and has an $\mathrm{A}+\mathrm{T}$ content of $67 \%$. The transposase intron positions of Boto are different from 
(a)

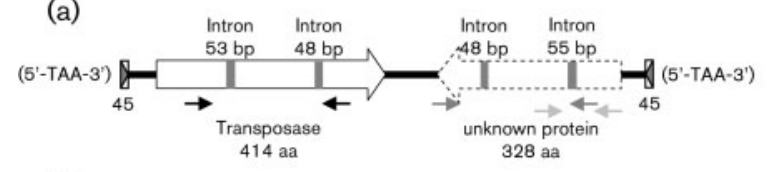

(b)

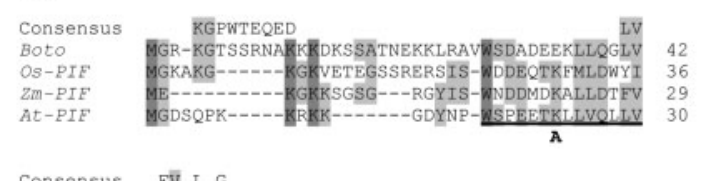

\section{Consensus
Boto
Os-PIF
ZM-PIF \\ Zm-PIF}

(1)

Consensus
Boto
Os-PIF
2m-PIF
At-PIF

Consensus

Boto

$2 m-P I F$
$O S-P I F$

At-PIF
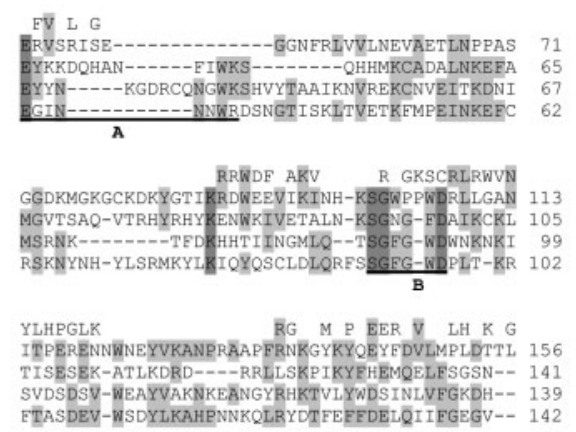

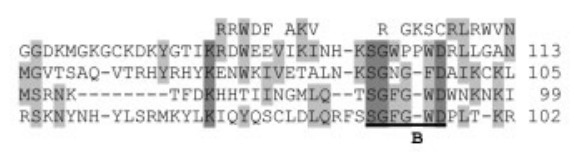

(c)
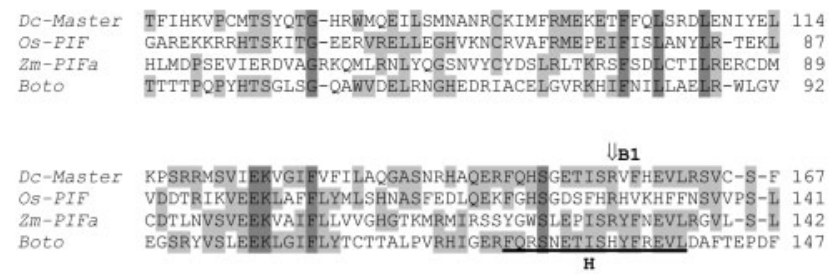

DC-Master
OS-PIF
Zm-PIFa
Boto

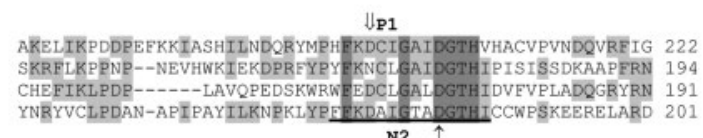

N2

$\Downarrow_{\mathrm{P} 2}$

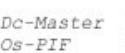

OS-PIF

$Z m-P I F$

Boto
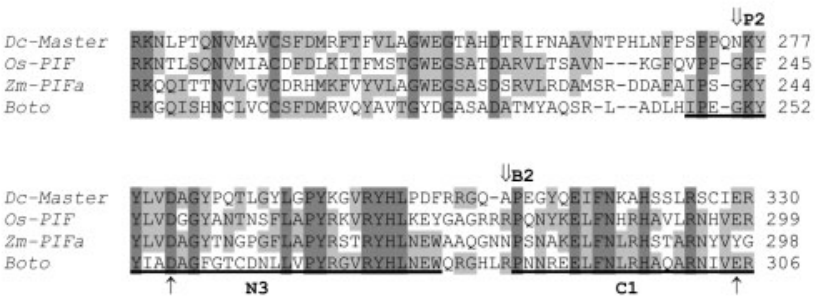

Fig. 1. (a) Schematic representation of the Boto element. The dotted arrow indicates the presence of ORF1 exhibiting low sequence similarity to the myb transcription factor. Grey boxes represent introns; small black arrows represent primers CPORT1 and CPORT2 used in the Southern blot, PCR and RT-PCR analyses; and small light and dark grey arrows represent primers Boto2ORF1F1, Boto2ORF1R1, Boto2ORF1F2 and Boto2ORF1R2 used to analyse ORF1 intron size and position. (b) Multiple alignments of the selected PIF/Harbinger ORF1. A and B indicate the two most conserved blocks identified by Zhang et al. (2004). 'Consensus' indicates the consensus amino acid residues obtained by the alignment of some plant myb transcription factors (Oryza sativa, AY398581; Arabidopsis thaliana, NM_114482; and Glycine max, DQ822919). The residues highlighted in grey are conserved among the analysed ORF1 proteins (Os-PIF, AC078977; Zm-PIF, EU949209; and At-PIF, NM_122608). (c) Multiple alignments of the Boto transposase protein with transposases described for plant PIFI Harbinger elements (Os-PIF, AAP52086; Zm-PIFa, AF412282; and DC-Master, ABB83644). Only the most conserved regions are presented. The horizontal lines indicate the $\mathrm{HTH}$ domain $(\mathrm{H})$ and the three regions of conserved amino acids $(\mathrm{N} 2$, $\mathrm{N} 3$ and $\mathrm{C} 1$ ) that must contain the catalytic domain of the enzyme (Zhang et al., 2004). The residues highlighted in grey are conserved among the analysed transposases. The DDE domain is indicated by $(\uparrow)$; $(\Downarrow)$ indicates the position of the following elements: $\Downarrow \mathrm{B} 1$, intron 1 of the Boto element; $\Downarrow \mathrm{B} 2$, intron 2 of the Boto element; $\Downarrow \mathrm{P} 1$, intron 1 of plant PIF-like elements; and $\Downarrow \mathrm{P} 2$, intron 2 of plant PIF-like elements.

those reported for plant PIF-like elements (Zhang et al., 2004). Introns 1 and 2 in the plant PIF-like transposase coding region are located 6 aa residues upstream from the first and second Asp (D) of the DDE domain, respectively (Zhang et al., 2004), but, in the Boto element, intron 1 was located 50 aa upstream from the first Asp of the DDE domain and intron 2 was located 28 aa downstream from the second Asp of the DDE domain (Fig. 1c).

\section{Boto ORF1 also contains two introns}

The sequence downstream of the transposase coding region contains a second ORF of $1090 \mathrm{bp}$, interrupted by two introns and coding for a 328 aa protein with low similarity to the DNA-binding domain of the $m y b$ transcription factor (Fig. 1b). Comparing that ORF with a sequence (EEB88797) presented in the Witches' Broom Genome Project Database allowed the identification of two additional thymines in the Boto ORF1 at positions +1067 and +1147 (based on the first ATG), which are responsible for the appearance of a premature stop codon. The removal of these additional thymines resulted in a 1372 bp ORF1 coding for a 422 aa protein, where the distance from the transposase stop codon and the ORF1 stop codon was only 16 bases. The presence of the two introns was confirmed by sequencing of PCR fragments amplified from ORF1 using CDNA and genomic DNA as templates (data not shown). These two introns are 55 bp with an $\mathrm{A}+\mathrm{T}$ content of $58.2 \%$, and 48 bp with an $\mathrm{A}+\mathrm{T}$ content of $75.0 \%$.

The Boto ORF1 intron position could not be compared with other fungal ORF1 sequences, and, although introns have been described in other PIF/Harbinger ORF1 sequences, the presence of two introns appears to be unusual. Analysis of the Boto ORF1 protein along with ORF1 proteins of plant PIF/Harbinger elements revealed the presence of some conserved blocks (Fig. 1b) previously identified by Zhang et al. (2004). 
(a)
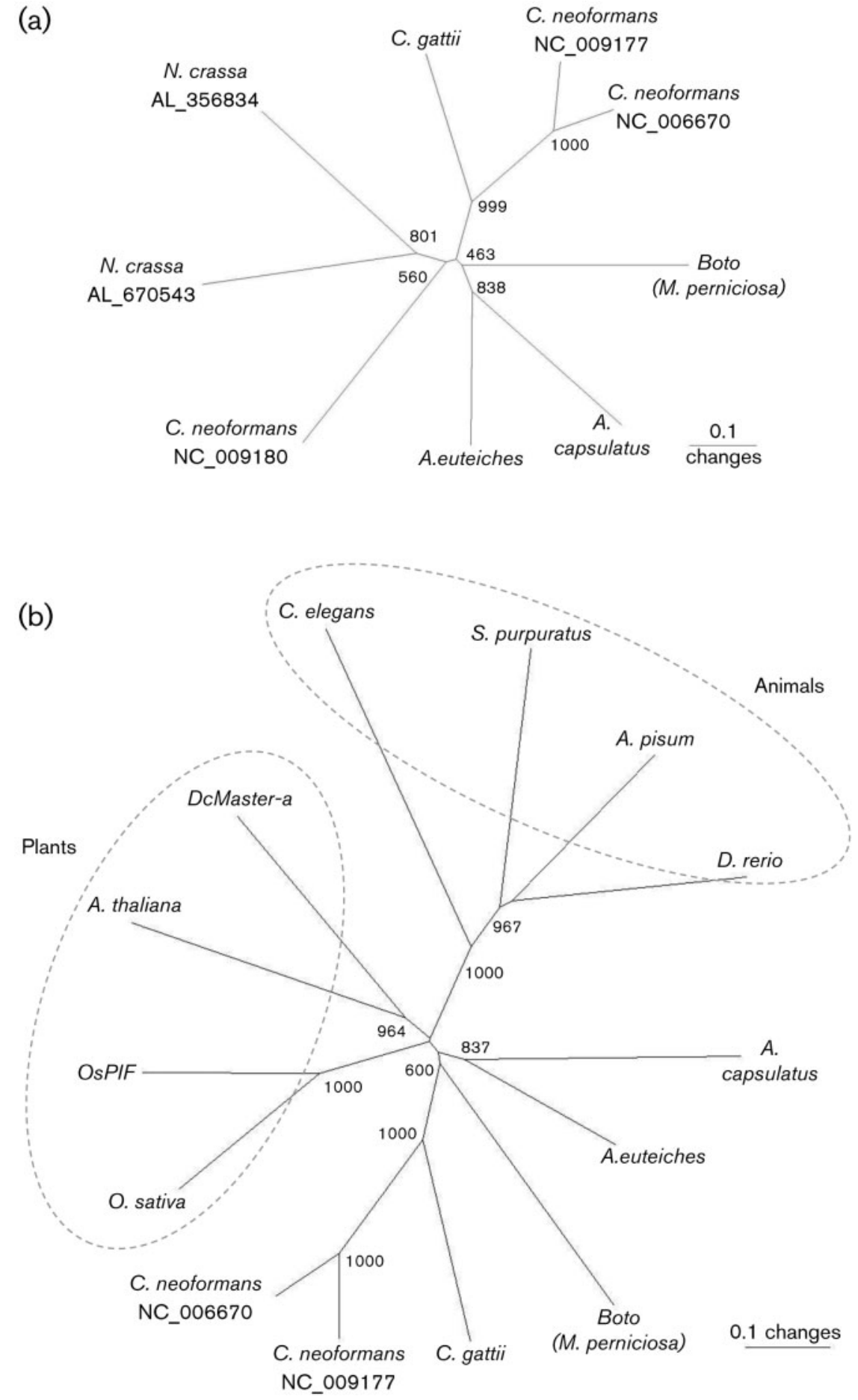

Fig. 2. Phylogenetic tree for Boto transposase. Trees were built with fungal and oomycete PIF/Harbinger-like transposases (a), and fungal, oomycete, plant and animal PIF-like tranposases (b). The trees were constructed by using the neighbour-joining method (Saitou \& Nei, 1987). Numbers indicate the percentage of bootstrap replicates from a sample of 1000 that support the branches. Sequences are named according to the species or the elements. GenBank accession nos: Acyrthosiphon pisum (AC202214), Ajellomyces capsulatus (XM_001541700), Aphanomyces euteiches (CU363155), Arabidopsis thaliana (AC005850), Boto (EU218539), Caenorhabditis elegans (NM_062114), Cryptococcus gatti (XM_003102814), Cryptocossus neoformans (NC_006670, 787098-788500; NC_009177, 778738-779561; NC_009180, 174072175467), Danio rerio (XM_001921333), DcMaster-a (DQ250806), Neurospora crassa (AL670543, 39714-39364; AL356834, 64784-64443), Oryza sativa (NM_001070615), OsPIF (NM_001070686) and Strongylocentrotus purpuratus (XM_788866). 


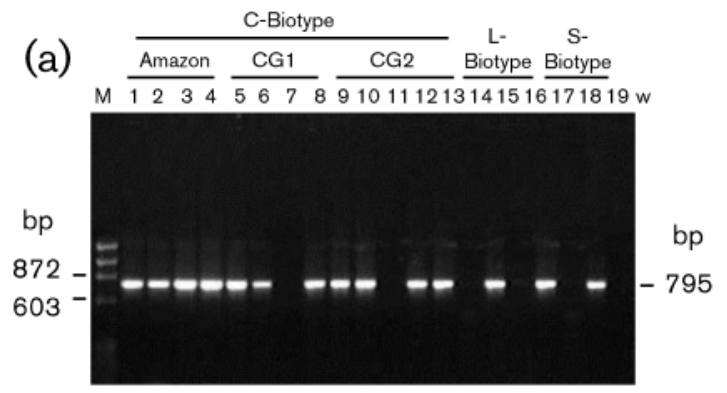

(b)

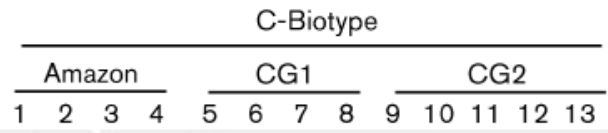

bp

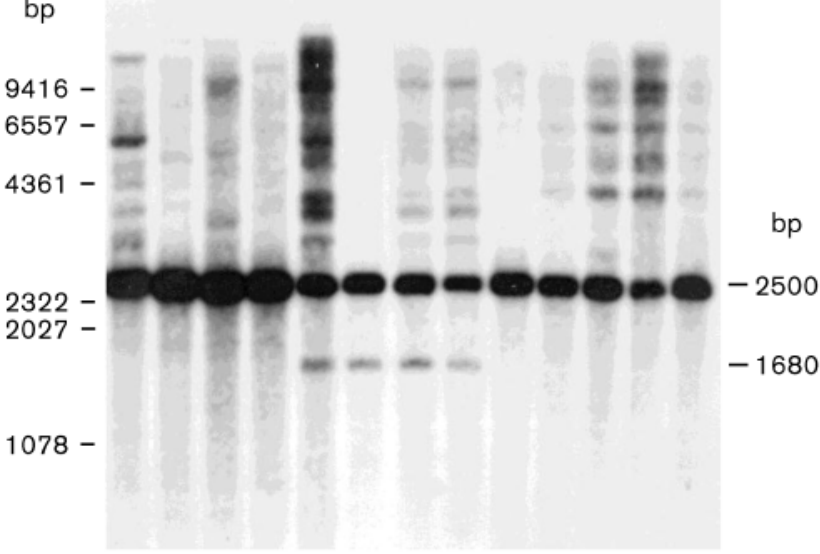

L- S-

Biot. Biotype

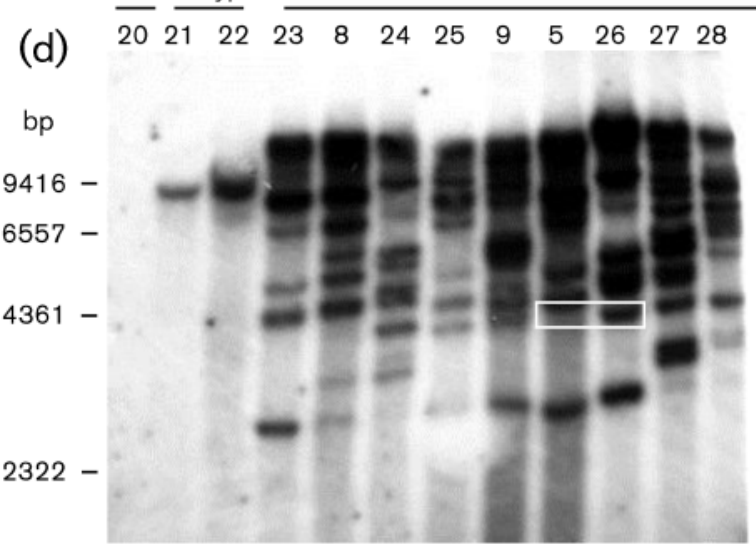

(c) $\frac{\text { L-Biotype }}{14 \quad 15 \quad 16} \frac{\text { S-Biotype }}{17 \quad 18 \quad 19}$

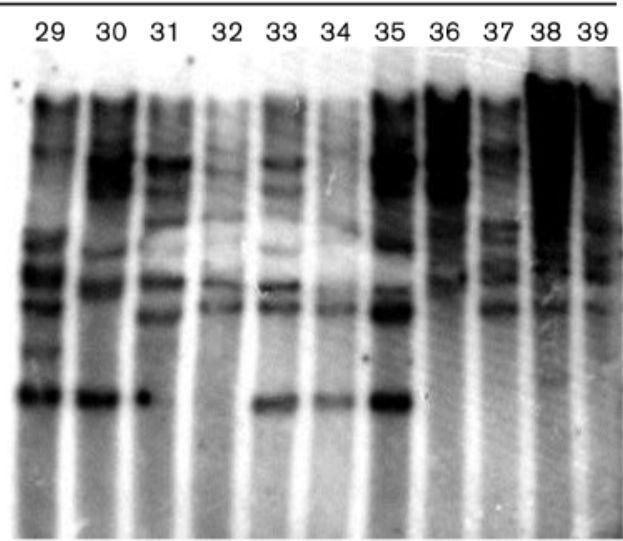

Fig. 3. $P C R$ and hybridization analyses of the C-, S- and L-biotype isolates of M. perniciosa. (a) Amplification of a 795 bp fragment containing part of the Boto transposase coding region. (b, c) Hybridizations, performed at $58{ }^{\circ} \mathrm{C}$, of $M$. perniciosa total DNA cleaved with Hindlll. (d) Hybridizations, performed at $65{ }^{\circ} \mathrm{C}$, of M. perniciosa total DNA digested with Sall. White rectangle indicates the new Boto insertion in the CP02 isolate. In all hybridization experiments, the 795 bp Boto transposase fragment was used as the probe. See Table 1 for identification of isolates 1-39.

\section{Boto and other fungal PIF-like transposases belong to the same phylogenetic cluster}

A phylogenetic tree was constructed based on the transposase protein deduced from Boto and the transposases and putative proteins of fungi and an oomycete (Fig. 2a), and plants and animals (Fig. 2b). The sequences from N. crassa and one from C. neoformans (NC_009180), when analysed together with the putative transposases of plants and animals, resulted in branches with low bootstrap values (data not shown). Boto, the oomycete (Aphanomyces 

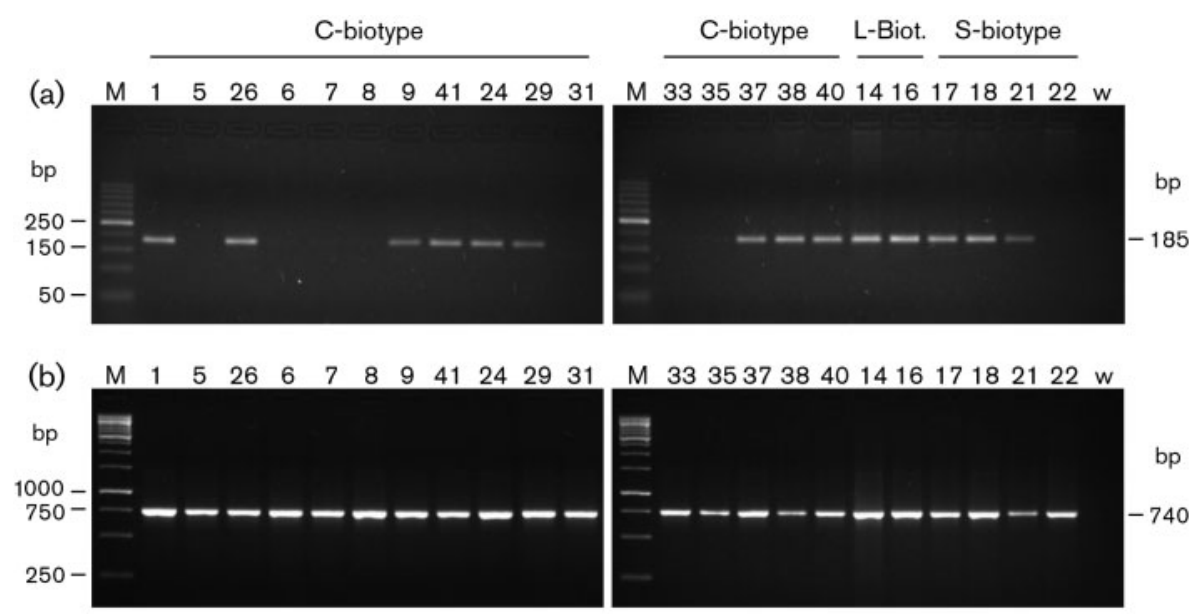

\begin{tabular}{|c|c|c|c|c|c|}
\hline Isolate & Biotype & Insertion site & TSD & Boto & Insertion site \\
\hline Boto & $\mathrm{C}$ & TAACCTAAAAGACAC & $\mid$ TAA $\mid$ & GGGC $\ldots . \mathrm{GCCC}$ & ATTCTTGCGGGAAGT \\
\hline 1- FA551 & c & TAACCTAAAAGACAC & TAA & & TTCTTGCGGGAAGT \\
\hline $26-\mathrm{CPO} 2$ & $\mathrm{c}$ & TAACCTAAAAGACAC & TAA & & TTCTTGCGGGAAGT \\
\hline 9 - S. Amaro & c & TAACCTAAAAGACAC & TAA & & TTCTTGCGGGAAGT \\
\hline $41-S A B A$ & c & TAACCTAAAAGACAC & TAA & & TTCTTGCGGGAAGT \\
\hline $24-$ FA281 & C & TAACCTAAAAGACAC & TAA & & TTCTTGCGGGAAGT \\
\hline $29-\operatorname{ALF} 276$ & C & TAACCTAAAAGACAC & TAA & & TTCTTGCGGGAAGT \\
\hline $37-896 \mathrm{FD}-\mathrm{W}$ & C & TAACCTAAAAGACAC & TAA & & TTCTTGCGGGAAGT \\
\hline $38-948 \mathrm{FD}-W$ & $\mathrm{c}$ & TAACCTAAAAGACAC & TAA & & TTCTTGCGGGAAGT \\
\hline $40-$ FA317 & c & TAACCTAAAAGACAC & TAA & & TTCTTGCGGGAAGT \\
\hline 14 - Lep 1 & L & TAACCTAAAAGACAC & TAA & & TTCTTGCGGGAAGT \\
\hline $16-\operatorname{SCL} 4$ & L & TAACCTAAAAGACAC & TAA & & TTGTTGCGGGAAGT \\
\hline 17 - FA607 & $\mathrm{s}$ & TAACCTAAAAGACAC & TAA & & TTCTTGCGGGAAGT \\
\hline $18-$ FA609 & $\mathrm{s}$ & TAACCTAAAAGACAC & TAA & & TTCTTGCGGGAAGT \\
\hline $21-$ RWB500 & $s$ & TAACCTAAAAGACAC & $\mid$ TAA $\mid$ & & TTCTTGCGGGAAGT \\
\hline
\end{tabular}

Fig. 4. (a) PCR analysis (separated on a $1.5 \%$ agarose gel) for detection of regions without Boto insertion. The annealing sites for primers Boto2.1 and Boto2.2 flank the region where Boto was characterized, and a 185 bp PCR fragment is expected if Boto is not present in that region. ' $\mathrm{M}$ ' indicates the molecular size marker (50 bp ladder). (b) ITS amplification as a DNA quality control. ' $\mathrm{M}$ ' indicates the molecular size marker ( $1 \mathrm{~kb}$ ladder). The reaction control without DNA is denoted by ' $w$ ', and numbers indicate M. perniciosa isolates (see Table 1). (c) Sequence analysis for detection of Boto excision footprints. 'TSD' indicates the target site duplication. Underlined ' $G$ ' indicates the $G: C$ transversion in isolate SCL4.

euteiches) protein, and the four other fungal transposases (C. neoformans NC_006670, C. neoformans NC_009177, C. gattii and A. capsulatus) grouped in the same branch (Fig. 2b).

\section{Boto is ubiquitously distributed among $M$. perniciosa}

The distribution analyses of Boto throughout the genomes of isolates from C-, S- and L-biotypes from the Amazon region and the states of Bahia and Minas Gerais, in Brazil, were performed by PCR and Southern hybridization (Fig. 3). In the PCR analysis, primers CPORT1 and CPORT2 were not able to amplify the $795 \mathrm{bp}$ fragment in some isolates (Fig. 3a) but Boto was detected in those same isolates by hybridization analysis (Fig. 3b, c). This is probably due to mutations in the annealing sites of the primers. DNA quality did not interfere in the PCR analysis once we were able to amplify the internal transcribed spacer region (ITS) in all isolates (data not shown). Southern hybridization did not detect any Boto sequences in isolate 20, belonging to the L-biotype, and only one copy was found in the S-biotype isolates (Fig. 3d). The Cbiotype strains, when analysed with the SalI enzyme, exhibited from six to 12 copies of the Boto element (Fig. $3 \mathrm{~d})$. When analysed with the HindIII enzyme, the Cbiotype isolates from Bahia State were divided into two groups by the presence of a $1.68 \mathrm{~kb}$ fragment according to their chromosomal groups (Fig. 3b). This fragment was not detected in the Amazon isolates or in the L- and Sbiotype isolates analysed (Fig. 3b, c). Two different cultures of isolate CP02, the same isolate used in the Witches' Broom Genome Project, were analysed: cultures CP02 and CP02-1. Culture CP02 was maintained as a stock in tubes with water, and culture CP02-1 was successively grown in PDA medium in the laboratory for 6 years. Fig. 3(d) shows the variation in the Boto element profiles of these two cultures. 


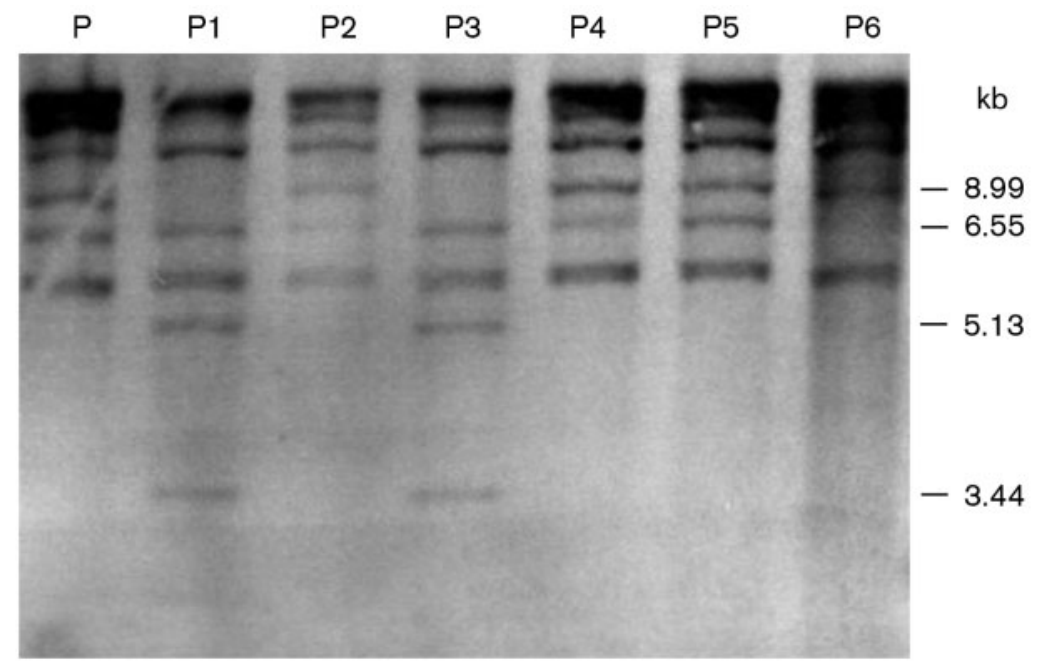

Fig. 5. Hybridization profile of an M. perniciosa parental isolate and six isolates from its progeny after the sexual cycle. Total DNA from M. perniciosa was cleaved with Sall, and hybridization was performed at $65^{\circ} \mathrm{C}$. The 795 bp PCR fragment containing part of the Boto transposase was used as a probe. ' $P$ ' indicates the parental isolate (1919; see Table 1 for more details), and 'P1-P6' indicate the six isolates obtained from its offspring after the M. perniciosa sexual cycle.

\section{Boto excision is not perfect}

Based on the flanking regions of the Boto transposon, a primer set was designed to analyse the putative excision footprints. The extension time used to amplify that specific region was short $(30 \mathrm{~s})$, and was less than the time necessary for the amplification of the whole element (3089 bp). In the analyses of $22 \mathrm{M}$. perniciosa isolates, the expected PCR fragment (185 bp) was detected in 14 isolates belonging to C-, S- and L-biotypes (Fig. 4a). Among those isolates, the cultures $\mathrm{CP} 02$ (maintained in stock) and CP02-1 (cultivated in our laboratory for 6 years) were negative and positive, respectively, indicating that Boto transposed from that site in culture CP02-1. Sequence analysis of the $185 \mathrm{bp}$ fragment in isolate CP02-1 with Boto flanking regions revealed that (i) the TAA is not duplicated and (ii) the first adenine, downstream of the duplicated TAA in the Boto element, is not present in the CP02-1 isolate (Fig. 4c). Those same characteristics were found in all of the other 13 sequences, in addition to a G : C transversion in isolate SCL4, three bases downstream of the TAA. Once Boto was identified through the genome sequencing of isolate $\mathrm{CP} 02$, analysis of isolates $\mathrm{CP} 02$ and CP02-1 provided evidence that Boto removes one copy of the 3 bp (TAA) target site duplication and just one other base during transposition. This finding is different from those reported for the mPing and Harbinger elements where a high proportion of 'perfect' excision (when, after the excision, the sequence at the insertion site is the same as before the insertion) was found (Yang et al., 2007; Sinzelle et al., 2008).

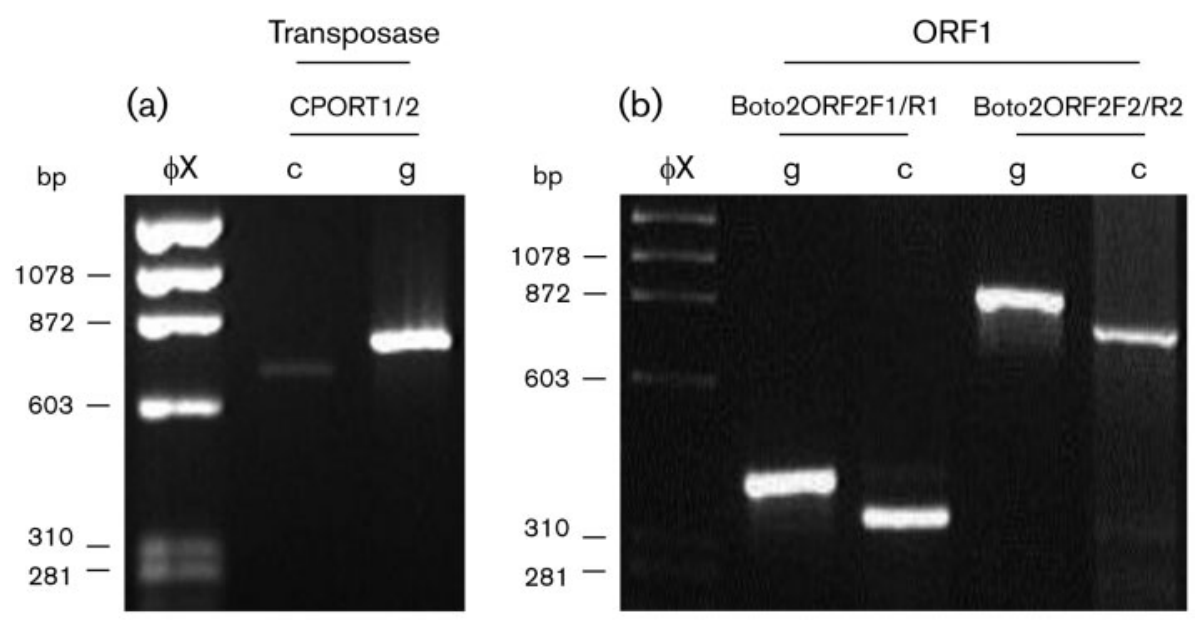

Fig. 6. Partial RT-PCR amplification of Boto transposase (with primers CPORT1/2) (a) and ORF1 (with primers Boto2ORF1F1/R1 and Boto2ORF1F2/R2) (b) genes using genomic DNA (g) and cDNA (c) from isolate CP02-1. The expected sizes for the PCR products are 795 or 694 bp (for primers CPORT1/2), 402 or 347 bp (for primers Boto2ORFF1/ $\mathrm{R} 1$ ) and 896 or 794 bp (for primers Boto2ORFF2/R2) using genomic DNA or cDNA, respectively. ' $\phi \mathrm{X}$ ', Molecular size marker (DNA from $\phi$ X174 phage cleaved with HaellI). 


\section{A different Boto hybridization pattern is detected after the $M$. perniciosa sexual cycle}

To analyse Boto transposition during the M. perniciosa sexual cycle, isolate 1919 was used to compare the Boto hybridization pattern with the pattern of its progeny (Fig. 5). Using the $795 \mathrm{bp}$ Boto transposase fragment as a probe, six Boto copies were detected in the parental isolate, and a modified hybridization pattern was observed in some of its progeny. Isolates $\mathrm{P} 1$ and $\mathrm{P} 3$ had lost the $8.99 \mathrm{~kb}$ fragment, and two new fragments $(3.44$ and $5.13 \mathrm{~kb}$ ) were detected, while isolate P6 had lost the $6.55 \mathrm{~kb}$ fragment. The variation in the hybridization pattern of these isolates could be explained by (i) Boto transposition to a new site (in isolates $\mathrm{P} 1$ and $\mathrm{P} 3$ ) and Boto excision without reinsertion (in isolate P6), (ii) recombination or (iii) a combined action of the two mechanisms.

\section{Amplification of Boto transcripts}

The activity of Boto in M. perniciosa was also analysed by RT-PCR (Fig. 6). RNA was extracted from a culture grown in minimal media, and Boto transcripts related to the transposase and ORF1 genes were amplified (Fig. 6). The sizes of the DNA fragments amplified from the cDNA were smaller than those amplified from genomic DNA, thus confirming the presence of the introns (Fig. 6).

\section{DISCUSSION}

Even though in silico analysis has revealed a higher number of class I than class II transposable elements in $M$. perniciosa (Mondego et al., 2008), we were able to identify, at the start of the Witches' Broom Genome Project, a rare transposase sequence for a phytopathogenic fungus. This paper describes the complete characterization of that class II element, named Boto, in the M. perniciosa genome. Some characteristics of the Boto transposon are similar to those of PIF/Harbinger elements, including: (i) 3 bp (TAA) target site duplication; (ii) small TIRs (45 bp); (iii) a second ORF (at the -2 frame) that codes for a protein exhibiting low sequence similarity to the plant $m y b$ transcription factor; (iv) sequence similarity of Boto transposase as well as the $\mathrm{DD}^{48} \mathrm{E}$ spacing; and (v) two introns at the transposase coding region. PIF-like and Pong-like elements of plants also have a $3 \mathrm{bp}$ TSD, which is usually TTA or TAA, although the PIF-like element TSD was characterized as AAT in C. neoformans (Zhang et al., 2001). A 3 bp TSD was also characterized in all autonomous and non-autonomous Harbinger elements analysed by Kapitonov \& Jurka (2004). Although the length of TIRs for Harbinger elements may vary from 10 to $700 \mathrm{bp}$ (Kapitonov \& Jurka, 2004), the size varies from 10 to $45 \mathrm{bp}$ in the PIF-like elements of rice (Zhang et al., 2004), similar to the $45 \mathrm{bp}$ size determined for the Boto element TIRs. As described for TIRs from most OsPIFs and OsPongs elements, the Boto TIRs also begin with 5'-GGSG-3' (where S represents G or C). Specific PIF or Pong inner TIR motifs were not identified, although bases $6-14$ in the Boto TIRs (5'-TGTTCGGTA-3') are more similar to PIF (5'-TGTTTGGTT-3') than Pong elements (Zhang et al., 2004). ORF1 exhibits weak similarity to transcription factors that may have a possible role in the transposition mechanism (Kapitonov \& Jurka, 2004; Zhang et al., 2004; Yang et al., 2007; Sinzelle et al., 2008; Hancock et al., 2010). Assuming a role of ORF1 in transposition, it is possible that Boto transposition could be achieved by cross-mobilization if the Boto ORF1 protein fails to produce a functional protein due to the presence of two additional thymines in its coding region.

The PIF/Harbinger elements are not abundantly distributed in fungal genomes. This fact is not a reflection of the number of fungal genomes currently available because close to 500 genomes, including yeasts, are sequenced or near completion (Keyhani, 2011). At least two hypotheses can explain the low distribution of the PIF/Harbinger elements in fungal genomes: (i) these elements have been lost during evolution in the majority of the fungal species studied so far or (ii) horizontal transfer spreads these elements to only some fungal genomes. The hypothesis of horizontal transfer is supported by the sporadic and nonhomogeneous distribution of PIF/Harbinger transposases observed in fungi, having only been detected in three human-pathogenic fungi (C. neoformans, C. gattii and A. capsulatus), one saprotrophic fungus ( $N$. crassa) and one phytopathogen (M. perniciosa). Such non-uniform distribution of an element within isolates of a single species (or within the same group, as in the present case) may reflect the recent acquisition of this element (Daboussi \& Capy, 2003). Horizontal transfer was hypothesized to have a role in the distribution of Harbinger transposons in plants (Kapitonov \& Jurka, 2004) and in some fungal transposons from different classes and superfamilies (Dobinson et al., 1993; Daboussi \& Langin, 1994; He et al., 1996; Shull \& Hamer, 1996; Nakayashiki et al., 1999; Shim \& Dunkle, 2005). Although in the phylogenetic analysis of Boto, one oomycete and four fungal transposases grouped in the same branch (Fig. 2b), Zhang et al. (2004) reported that PIF-like transposases in C. neoformans and N. crassa formed two distinct species-specific groups that failed to show a common ancestor when analysed with 600 other PIF-like transposases of plants and animals. Undoubtedly, more detailed analyses are necessary to elucidate the polyphyletic nature of fungal PIF-like transposases, but the role of horizontal transfer cannot be ruled out.

MITEs are present in high copy numbers in plant genomes (Wessler et al., 1995). Given that PIF/Harbinger elements are present in several plant species and are directly linked to the origin and mobilization of MITEs in plants (Zhang et al., 2001, 2004; Kapitonov \& Jurka, 2004; Grzebelus et al., 2006), the wide distribution of MITEs in plants can be expected. Therefore, the low distribution of PIF/Harbinger elements in fungal genomes may be related to the small number of MITE-like elements found in filamentous fungi (Yeadon \& Catcheside, 1995; Hua-Van et al., 2000; Fleetwood et al., 2007, 2011). Although the PIF/Harbinger 
elements have been identified as sources of transposases for Tourist-like MITEs in maize and rice (Zhang et al., 2001; Jiang et al., 2003), the cross-mobilization of the mimp elements from Fusarium oxysporum was linked to the impala transposase, an element of the TC1/Mariner superfamily (Dufresne et al., 2007; Bergemann et al., 2008).

In M. perniciosa, Boto elements were found to be ubiquitous among the analysed isolates belonging to the C-, L- and S-biotypes (Fig. 3). Although a $2.5 \mathrm{~kb}$ HindIII DNA fragment is conserved in the M. perniciosa isolates analysed (Fig. 3b, c), a $1.68 \mathrm{~kb}$ HindIII fragment did distinguish the C-biotypes from Bahia State, the major state of cacao production in Brazil, into two different groups related to the chromosomal groups described by Rincones et al. (2006). Genetic variability studies in $M$. perniciosa, using several different molecular techniques, have revealed two different genotypic groups in Bahia State and genetically close relationships between a number of isolates from that state with isolates from the Amazon region. Those data have been used to propose (Andebrhan et al., 1999) and to corroborate the hypothesis (de Arruda et al., 2003a, b; Rincones et al., 2003) that the witches' broom outbreak in Bahia State occurred by two independent focal points of introduction. Moreover, a reverse transcriptase sequence, part of a putative gypsy-like retrotransposon, and a transposase sequence, belonging to the TC1-Mariner superfamily, also distinguished C-biotype isolates from Bahia in two genotypic groups (Pereira et al., 2007; Ignacchiti et al., 2011). Thus, some transposable elements appear to spread through the $M$. perniciosa genome in accordance with some chromosomal groups.

Different strategies could be used to demonstrate transposon activity such as gene inactivation (Daboussi et al., 1992; Langin et al., 1995; Maurer et al., 1997; Gómez-Gómez et al., 1999; Ogasawara et al., 2009), detection of new insertions in the genome (Anaya \& Roncero, 1996; Mes et al., 2000) or through expression analyses (Okuda et al., 1998; Kaneko et al., 2000; Kito et al., 2003; Rep et al., 2005; Ogasawara et al., 2009). For Boto elements of M. perniciosa, the last two strategies were used to give experimental support to their expression and activity, including (i) variation found in the hybridization profiles in different cultures of isolate CP02 (Fig. 3d); (ii) PCR amplification from the specific site where Boto was characterized (Fig. 4); (iii) different hybridization patterns in three isolates originated after the M. perniciosa sexual cycle (Fig. 5); (iv) successful amplification of Boto transcripts (Fig. 6); and (v) variation in the copy number and location in different isolates of this fungus (Fig. 3). Thus, we conclude that the Boto family is active and may contribute to the genetic variability in $M$. perniciosa.

One possible explanation for the Boto activity observed when $M$. perniciosa was subjected to the sexual cycle is based on the idea that transposable elements could be activated under stress conditions. That idea is supported by the fact that transposition contributes to the generation of genetic variability, which could confer adaptive advantages to the organism under environmental stress (McClintock, 1984). Other genes involved in transposition and retrotransposition appear to be activated during the $M$. perniciosa life cycle and were found among the 189 genes that showed significantly different expression between biotrophic-like and saprotrophic mycelia (Rincones et al., 2008). Moreover, transposition activity is not necessary for the mutagenic effects of transposable elements, as the copies throughout the genome can be used for reorganization through ectopic recombination (Daboussi \& Capy, 2003; Shnyreva, 2003).

The presence of the two introns in the Boto transposase coding region was confirmed by RT-PCR. Sequencing data revealed that these introns are small and show a high $\mathrm{A}+\mathrm{T}$ content, thus resembling the introns found in plant PIFlike elements. However, the intron position found in the Boto element differs from that reported for plant PIF-like elements. The first intron $(53 \mathrm{bp})$ is located 50 aa residues upstream of the first Asp (D) of the DDE domain, and the second intron (48 bp) is located 28 aa residues downstream of the second Asp (D) of the DDE domain. In PIF/ Harbinger elements, different arrangements are found for the ORFs that code for the transposase and the protein of unknown function (Kapitonov \& Jurka, 2004; Zhang et al., 2004). These ORFs may be oriented in the same or in opposite directions, and the transposase ORF can be found upstream or downstream of the unknown protein ORF. The arrangement found in the Boto transposon (ORFs in opposite directions and the transposase ORF upstream of the unknown protein ORF) has not been described for plant PIF/Harbinger elements (Zhang et al., 2004) but is similar to the arrangements found in some families of Harbinger elements in animals (Anopheles gambiae and zebrafish) and a protist (Thalassiosira pseudonana) (Kapitonov \& Jurka, 2004).

Considering our results, the Boto element of M. perniciosa has evolved differently from previously described PIF/ Harbinger elements, and a few differences are thus expected between the transposases of these elements. Given the particular characteristics with regard to transposase intron position, the organization of the second ORF and the footprint, the Boto element of $M$. perniciosa belongs to a new family of transposable elements of the PIF/Harbinger superfamily. This is an active family of transposable elements in $M$. perniciosa that may contribute to the genome plasticity and adaptability of this phytopathogenic fungus.

\section{ACKNOWLEDGEMENTS}

We gratefully acknowledge the Brazilian agencies $\mathrm{CNPq}$ (Conselho Nacional de Desenvolvimento Científico e Tecnológico), CAPES (Coordenação de Aperfeiçoamento de Pessoal de Nível Superior), FAPESP (Fundação de Amparo à Pesquisa do Estado de São Paulo) and SEAGRI (Secretaria de Agricultura do Estado da Bahia) for financial support. Dr A. Leyva helped with the English editing of the manuscript. 


\section{REFERENCES}

Altschul, S. F., Madden, T. L., Schäffer, A. A., Zhang, J., Zhang, Z., Miller, W. \& Lipman, D. J. (1997). Gapped BLAST and PSI-BLAST: a new generation of protein database search programs. Nucleic Acids Res 25, 3389-3402.

Anaya, N. \& Roncero, M. I. G. (1996). Stress-induced rearrangement of Fusarium retrotransposon sequences. Mol Gen Genet 253, 8994.

Andebrhan, T. \& Furtek, D. B. (1994). Random amplified polymorphic DNA (RAPD) analysis of Crinipellis perniciosa isolates from different hosts. Plant Pathol 43, 1020-1027.

Andebrhan, T., Figueira, A., Yamada, M. M., Cascardo, J. \& Furtek, D. B. (1999). Molecular fingerprinting suggests two primary outbreaks of witches' broom disease (Crinipellis perniciosa) of Theobroma cacao in Bahia, Brazil. Eur J Plant Pathol 105, 167-175.

Bastos, C. N. \& Evans, H. C. (1985). A new pathotype of Crinipellis perniciosa (Witches' broom disease) on solanaceous hosts. Plant Pathol 34, 306-312.

Bastos, C. N., Andebrhan, T. \& de Almeida, L. C. (1988). Comparação morfológica de isolados de Crinipellis perniciosa. Fitopatol Bras 13 , 202-205.

Benton, W. D. \& Davis, R. W. (1977). Screening lambdagt recombinant clones by hybridization to single plaques in situ. Science 196, 180-182.

Bergemann, M., Lespinet, O., M'Barek, S. B., Daboussi, M. J. \& Dufresne, M. (2008). Genome-wide analysis of the Fusarium oxysporum mimp family of MITEs and mobilization of both native and de novo created mimps. J Mol Evol 67, 631-642.

Daboussi, M. J. \& Capy, P. (2003). Transposable elements in filamentous fungi. Annu Rev Microbiol 57, 275-299.

Daboussi, M. J. \& Langin, T. (1994). Transposable elements in the fungal plant pathogen Fusarium oxysporum. Genetica 93, 49-59.

Daboussi, M. J., Langin, T. \& Brygoo, Y. (1992). Fot1, a new family of fungal transposable elements. Mol Gen Genet 232, 12-16.

de Arruda, M. C., Ferreira, M. A., Miller, R. N., Resende, M. L. \& Felipe, M. S. (2003a). Nuclear and mitochondrial rDNA variability in Crinipellis perniciosa from different geographic origins and hosts. Mycol Res 107, 25-37.

de Arruda, M. C., Miller, R. N., Ferreira, M. A. \& Felipe, M. S. (2003b). Comparison of Crinipellis perniciosa isolates from Brazil by ERIC repetitive element sequence-based PCR genomic fingerprint. Plant Pathol 52, 236-244.

Dobinson, K. F., Harris, R. E. \& Hamer, J. E. (1993). Grasshopper, a long terminal repeat (LTR) retroelement in the phytopathogenic fungus Magnaporthe grisea. Mol Plant Microbe Interact 6, 114-126.

Dufresne, M., Hua-Van, A., El Wahab, H. A., Ben M'Barek, S., Vasnier, C., Teysset, L., Kema, G. H. J. \& Daboussi, M. J. (2007). Transposition of a fungal miniature inverted-repeat transposable element through the action of a Tc1-like transposase. Genetics 175, $441-452$

Evans, H. C. (1978). Witches' broom disease of cocoa (Crinipellis perniciosa) in Ecuador. Ann Appl Biol 89, 185-192.

Felipe, M. S. S., Azevedo, M. A., Vainstein, M. H. \& Schrank, A. (1992). Biologia molecular de fungos filamentosos: construção de banco genômico e de cDNA. In Manual Técnico, p. 99. Piracicaba, SP, Brazil: Escola Superior de Agricultura 'Luiz de Queiroz'.

Fleetwood, D. J., Scott, B., Lane, G. A., Tanaka, A. \& Johnson, R. D. (2007). A complex ergovaline gene cluster in epichloe endophytes of grasses. Appl Environ Microbiol 73, 2571-2579.

Fleetwood, D. J., Khan, A. K., Johnson, R. D., Young, C. A., Mittal, S., Wrenn, R. E., Hesse, U., Foster, S. J., Schardl, C. L. \& Scott, B. (2011)
Abundant degenerate miniature inverted-repeat transposable elements in genomes of epichloid fungal endophytes of grasses. Genome Biol Evol 3, 1253-1264.

Gómez-Gómez, E., Anaya, N., Roncero, M. I. G. \& Hera, C. (1999). Folyt1, a new member of the hAT family, is active in the genome of the plant pathogen Fusarium oxysporum. Fungal Genet Biol 27, 6776.

Goodwin, T. J. \& Poulter, R. T. (2001). The DIRS1 group of retrotransposons. Mol Biol Evol 18, 2067-2082.

Goodwin, T. J., Butler, M. I. \& Poulter, R. T. (2003). Cryptons: a group of tyrosine-recombinase-encoding DNA transposons from pathogenic fungi. Microbiology 149, 3099-3109.

Griffith, G. W. \& Hedger, J. N. (1993). A novel method for producing basidiocarps of the cocoa pathogen Crinipellis perniciosa using a branvermiculite medium. Eur J Plant Pathol 99, 227-230.

Grzebelus, D., Yau, Y. Y. \& Simon, P. W. (2006). Master: a novel family of PIF/Harbinger-like transposable elements identified in carrot (Daucus carota L.). Mol Genet Genomics 275, 450-459.

Hancock, C. N., Zhang, F. \& Wessler, S. R. (2010). Transposition of the Tourist-MITE mPing in yeast: an assay that retains key features of catalysis by the class 2 PIF/Harbinger superfamily. Mob DNA 1, 5 .

He, C., Nourse, J. P., Irwin, J. A. G., Manners, J. M. \& Kelemu, S. (1996). $C g T 1$ : a non-LTR retrotransposon with restricted distribution in the fungal phytopathogen Colletotrichum gloeosporioides. Mol Gen Genet 252, 320-331.

Hedger, J. N., Pickering, V. \& Aragundi, J. (1987). Variability of populations of the witches' broom disease of cocoa (Crinipellis perniciosa). Trans Br Mycol Soc 88, 533-546.

Hua-Van, A., Davière, J. M., Kaper, F., Langin, T. \& Daboussi, M. J. (2000). Genome organization in Fusarium oxysporum: clusters of class II transposons. Curr Genet 37, 339-347.

Ignacchiti, M. D. C., Santana, M. F., Araújo, E. F. \& Queiroz, M. V. (2011). The distribution of a transposase sequence in Moniliophthora perniciosa confirms the occurrence of two genotypes in Bahia, Brazil. Trop Plant Pathol 36, 276-286.

Jiang, N., Bao, Z., Zhang, X., Hirochika, H., Eddy, S. R., McCouch, S. R. \& Wessler, S. R. (2003). An active DNA transposon family in rice. Nature 421, 163-167.

Jurka, J. \& Kapitonov, V. V. (2001). PIFs meet Tourists and Harbingers: a superfamily reunion. Proc Natl Acad Sci U S A 98, 12315-12316.

Kaneko, I., Tanaka, A. \& Tsuge, T. (2000). REAL, an LTR retrotransposon from the plant pathogenic fungus Alternaria alternata. Mol Gen Genet 263, 625-634.

Kapitonov, V. V. \& Jurka, J. (1999). Molecular paleontology of transposable elements from Arabidopsis thaliana. Genetica 107, 27-37.

Kapitonov, V. V. \& Jurka, J. (2004). Harbinger transposons and an ancient HARBI1 gene derived from a transposase. DNA Cell Biol 23, 311-324.

Keyhani, N. O. (2011). Fungal genomes and beyond. Fungal Genom Biol 1, e101.

Kito, H., Takahashi, Y., Sato, J., Fukiya, S., Sone, T. \& Tomita, F. (2003). Occan, a novel transposon in the Fot1 family, is ubiquitously found in several Magnaporthe grisea isolates. Curr Genet 42, 322331.

Langin, T., Capy, P. \& Daboussi, M. J. (1995). The transposable element impala, a fungal member of the Tc1-mariner superfamily. Mol Gen Genet 246, 19-28.

Marchler-Bauer, A. \& Bryant, S. H. (2004). CD-Search: protein domain annotations on the fly. Nucleic Acids Res 32 (Web Server issue), W327-W331. 
Maurer, P., Réjasse, A., Capy, P., Langin, T. \& Riba, G. (1997). Isolation of the transposable element hupfer from the entomopathogenic fungus Beauveria bassiana by insertion mutagenesis of the nitrate reductase structural gene. Mol Gen Genet 256, 195-202.

McClintock, B. (1984). The significance of responses of the genome to challenge. Science 226, 792-801.

Mes, J. J., Haring, M. A. \& Cornelissen, B. J. C. (2000). Foxy: an active family of short interspersed nuclear elements from Fusarium oxysporum. Mol Gen Genet 263, 271-280.

Mondego, J. M. C., Carazzolle, M. F., Costa, G. G. L., Formighieri, E. F., Parizzi, L. P., Rincones, J., Cotomacci, C., Carraro, D. M., Cunha, A. F. \& other authors (2008). A genome survey of Moniliophthora perniciosa gives new insights into Witches' Broom Disease of cacao. BMC Genomics 9, 548.

Nakayashiki, H., Nishimoto, N., Ikeda, K., Tosa, Y. \& Mayama, S. (1999). Degenerate MAGGY elements in a subgroup of Pyricularia grisea: a possible example of successful capture of a genetic invader by a fungal genome. Mol Gen Genet 261, 958-966.

Niella, G., Resende, M. L., Castro, H. A., de Carvalho, G. A. \& Silva, L. H. C. P. (1999). Aperfeiçoamento da metodologia de produção artificial de basidiocarpos de Crinipellis perniciosa. Fitopatol Bras 24, 523-527.

Ogasawara, H., Obata, H., Hata, Y., Takahashi, S. \& Gomi, K. (2009). Crawler, a novel Tc1/mariner-type transposable element in Aspergillus oryzae transposes under stress conditions. Fungal Genet Biol 46, 441449.

Okuda, M., Ikeda, K., Namiki, F., Nishi, K. \& Tsuge, T. (1998). Tfol: an Ac-like transposon from the plant pathogenic fungus Fusarium oxysporum. Mol Gen Genet 258, 599-607.

Pereira, J. L., de Almeida, L. C. C. \& Santos, S. M. (1996). Witches' broom disease of cocoa in Bahia: attempts at eradication and containment. Crop Prot 15, 743-752.

Pereira, J. F., Araújo, E. F., Brommonschenkel, S. H. \& Queiroz, M. V. (2006). Elementos transponíveis em fungos fitopatogênicos. Rev Anual Patol Plant 14, 303-362.

Pereira, J. F., Ignacchiti, M. D. C., Araújo, E. F., Brommonschenkel, S. H., Cascardo, J. C. M., Pereira, G. A. G. \& Queiroz, M. V. (2007). PCR amplification and sequence analyses of reverse transcriptaselike genes in Crinipellis perniciosa isolates. Fitopatol Bras 32, 373380.

Ploetz, R. C., Schnell, R. J., Ying, Z. T., Zheng, O., Olano, C. T., Motamayor, J. C. \& Johnson, E. S. (2005). Analysis of molecular diversity in Crinipellis perniciosa with AFLP markers. Eur J Plant Pathol 111, 317-326.

Pontecorvo, G., Roper, J. A. L., Hemmons, L. M., MacDonald, K. D. \& Bufton, A. W. J. (1953). The genetics of Aspergillus nidulans. Adv Genet 5, 141-238.

Rep, M., van der Does, H. C. \& Cornelissen, B. J. (2005). Drifter, a novel, low copy hAT-like transposon in Fusarium oxysporum is activated during starvation. Fungal Genet Biol 42, 546-553.

Rincones, J., Meinhardt, L. W., Vidal, B. C. \& Pereira, G. A. G. (2003). Electrophoretic karyotype analysis of Crinipellis perniciosa, the causal agent of witches' broom disease of Theobroma cacao. Mycol Res 107, 452-458.

Rincones, J., Mazotti, G. D., Griffith, G. W., Pomela, A., Figueira, A., Leal, G. A., Jr, Queiroz, M. V., Pereira, J. F., Azevedo, R. A. \& other authors (2006). Genetic variability and chromosome-length polymorphisms of the witches' broom pathogen Crinipellis perniciosa from various plant hosts in South America. Mycol Res 110, 821832.

Rincones, J., Scarpari, L. M., Carazzolle, M. F., Mondego, J. M. C., Formighieri, E. F., Barau, J. G., Costa, G. G. L., Carraro, D. M.,
Brentani, H. P. \& other authors (2008). Differential gene expression between the biotrophic-like and saprotrophic mycelia of the witches' broom pathogen Moniliophthora perniciosa. Mol Plant Microbe Interact 21, 891-908.

Saitou, N. \& Nei, M. (1987). The neighbor-joining method: a new method for reconstructing phylogenetic trees. Mol Biol Evol 4, 406425.

Sambrook, J., Fritsch, E. F. \& Maniatis, T. (1989). Molecular Cloning: a Laboratory Manual, 2nd edn. Cold Spring Harbor, NY: Cold Spring Harbor Laboratory.

Sanger, F., Nicklen, S. \& Coulson, A. R. (1977). DNA sequencing with chain-terminating inhibitors. Proc Natl Acad Sci U S A 74, 54635467.

Schmidt, S. M. \& Panstruga, R. (2011). Pathogenomics of fungal plant parasites: what have we learnt about pathogenesis? Curr Opin Plant Biol 14, 392-399.

Shim, W. B. \& Dunkle, L. D. (2005). Malazy, a degenerate, speciesspecific transposable element in Cercospora zeae-maydis. Mycologia 97, 349-355.

Shnyreva, A. V. (2003). Transposable elements are the factors involved in various rearrangements and modifications of fungal genomes. Russ J Genet 39, 505-518.

Shull, V. \& Hamer, J. E. (1996). Genetic differentiation in the rice blast fungus revealed by the distribution of the Fosbury retrotransposon. Fungal Genet Biol 20, 59-69.

Sinzelle, L., Kapitonov, V. V., Grzela, D. P., Jursch, T., Jurka, J., Izsvák, Z. \& Ivics, Z. (2008). Transposition of a reconstructed Harbinger element in human cells and functional homology with two transposon-derived cellular genes. Proc Natl Acad Sci U S A 105, 4715-4720.

Specht, C. A., DiRusso, C. C., Novotny, C. P. \& Ullrich, R. C. (1982). A method for extracting high-molecular-weight deoxyribonucleic acid from fungi. Anal Biochem 119, 158-163.

Stanke, M. \& Morgenstern, B. (2005). AUGUSTUS: a web server for gene prediction in eukaryotes that allows user-defined constraints. Nucleic Acids Res 33 (Web Server issue), W465-W467.

Thompson, J. D., Higgins, D. G. \& Gibson, T. J. (1994). Clustal W: improving the sensitivity of progressive multiple sequence alignment through sequence weighting, position-specific gap penalties and weight matrix choice. Nucleic Acids Res 22, 4673-4680.

Walker, E. L., Eggleston, W. B., Demopulos, D., Kermicle, J. \& Dellaporta, S. L. (1997). Insertions of a novel class of transposable elements with a strong target site preference at the $r$ locus of maize. Genetics 146, 681-693.

Wessler, S. R., Bureau, T. E. \& White, S. E. (1995). LTRretrotransposons and MITEs: important players in the evolution of plant genomes. Curr Opin Genet Dev 5, 814-821.

Wicker, T., Sabot, F., Hua-Van, A., Bennetzen, J. L., Capy, P., Chalhoub, B., Flavell, A., Leroy, P., Morgante, M. \& other authors (2007). A unified classification system for eukaryotic transposable elements. Nat Rev Genet 8, 973-982.

Wöstemeyer, J. \& Kreibich, A. (2002). Repetitive DNA elements in fungi (Mycota): impact on genomic architecture and evolution. Curr Genet 41, 189-198.

Yang, G. J., Zhang, F., Hancock, C. N. \& Wessler, S. R. (2007). Transposition of the rice miniature inverted repeat transposable element mPing in Arabidopsis thaliana. Proc Natl Acad Sci U S A 104, 10962-10967.

Yeadon, P. J. \& Catcheside, D. E. (1995). Guest: a 98 bp inverted repeat transposable element in Neurospora crassa. Mol Gen Genet 247, 105-109. 
Zhang, X., Feschotte, C., Zhang, Q., Jiang, N., Eggleston, W. B. \& Wessler, S. R. (2001). $P$ instability factor: an active maize transposon system associated with the amplification of Tourist-like MITEs and a new superfamily of transposases. Proc Natl Acad Sci U S A 98, 12572-12577.

Zhang, X., Jiang, N., Feschotte, C. \& Wessler, S. R. (2004). PIF- and Pong-like transposable elements: distribution, evolution and relationship with Tourist-like miniature inverted-repeat transposable elements. Genetics 166, 971-986.
Zhou, M. B., Lu, J.-J., Zhong, H., Liu, X.-M. \& Tang, D.-O. (2010). Distribution and diversity of PIF-like transposable elements in the Bambusoideae subfamily. Plant Sci 179, 257-266.

Zhou, M. B., Liu, X. M. \& Tang, D. Q. (2012). PpPIF-1: first isolated full-length PIF-like element from the bamboo Phyllostachys pubescens. Genet Mol Res 11, 810-820.

Edited by: R. P. Oliver 